Received September 13; revised October 9, 1972.

' Pabst, A., Gross, E. B., and Alfors, J. T., Amer. Mineral., 52, 336 (1967).

2 Jeffery, J. W., Chem. Indust., 53, 1756 (1955).

\section{Stability of Di-imide}

DI-IMIDE, $\mathrm{HN}=\mathrm{NH}$, as the prototype azo compound and an isoelectronic analogue of $\mathrm{C}_{2} \mathrm{H}_{4}$ and $\mathrm{O}_{2}$, is of great interest to the chemist. It is, however, generally considered to be so unstable as to have only a transient existence at ordinary temperatures ${ }^{1-3}$. Generated in situ in aqueous solution, it has been widely used in recent years as a reducing agent ${ }^{3}$, but has never been isolated or detected in these systems. It has been detected as a transient in the gas phase in several laboratories. Foner and Hudson ${ }^{4}$ produced di-imide by an electric discharge through flowing hydrazine vapour, detected it by mass spectrometry, and showed that it could be trapped at $-196^{\circ} \mathrm{C}$ and regenerated in the gas phase on warming. Trombetti $\mathrm{i}^{5}$, in these laboratories, was able to measure the infrared and vacuum-ultraviolet absorption spectrum of the vapour in a similar flow system, and these two studies seemed to indicate a lifetime of at least a second or two. A brief account by Mock $^{6}$ suggests that the lifetime might be much longer; he observed that when di-imide vapour together with ammonia and hydrazine was admitted to the inlet manifold of a mass spectrometer, a signal at $m / e=30$ decayed with a half-life of several minutes and remained detectable for as long as $20 \mathrm{~min}$. Uncertainty and lack of reproducibility of these observations led Mock to conclude only tentatively that di-imide might be as long lived as these data suggest.

We have carried out a detailed study of the chemistry of di-imide, and have found the lifetime in the vapour phase to be surprisingly long, substantially in agreement with Mock's observations. Di-imide was generated by a microwave discharge in hydrazine vapour in a flow system. Hydrazine was trapped out at $-78^{\circ} \mathrm{C}$, while ammonia and di-imide condensed in a second trap at $-196^{\circ} \mathrm{C}$, the di-imide forming a ring of bright yellow solid just above the liquid nitrogen surface. The second trap was then isolated, and di-imide, together with about a ten-fold excess of ammonia, could be vaporized by rapid warming and its reactions observed in a static system. The vapour shows a weak "azo" absorption in the near ultra-

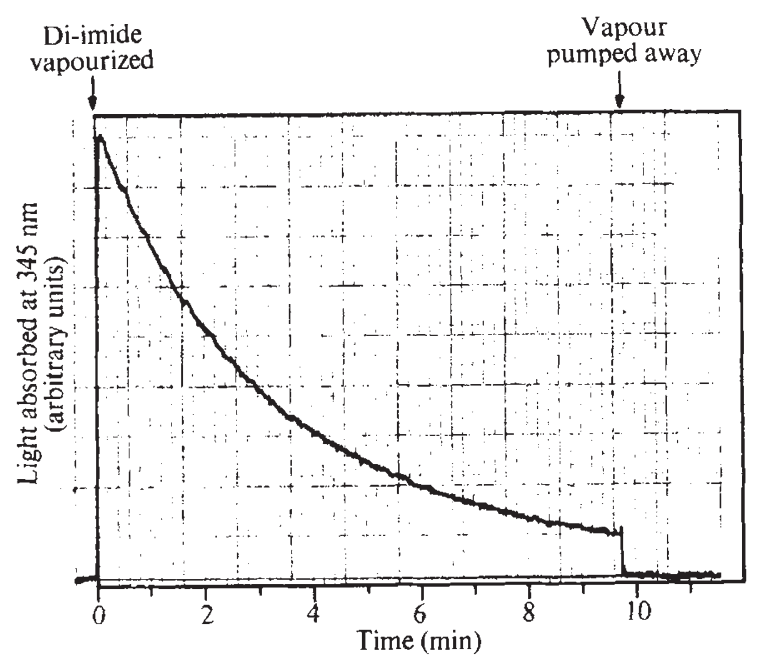

Fig. 1 Absorption of light at $345 \mathrm{~nm}$ by di-imide vapour, showing the disappearance with time at $30^{\circ} \mathrm{C}$. Initial absorption was about $5 \%$ and initial $\mathrm{N}_{2} \mathrm{H}_{2}$ pressure probably around was about $5 \%$, and initial $\mathrm{N}_{2} \mathrm{H}_{2}$ pressure probably around
10 torr (an accurate extinction coefficient has not yet been established). violet $(320-420 \mathrm{~nm})$ which, unlike the spectra of most azo compounds, has a pronounced banded structure. This absorption provided a convenient means of measuring the concentration; Fig. 1 shows a typical decay of di-imide vapour at $30^{\circ} \mathrm{C}$ measured in this way in a cylindrical spectrophotometer cell $2 \mathrm{~cm}$ in diameter and $10 \mathrm{~cm}$ long. The decay in this instance was first-order with a half life of $2.4 \mathrm{~min}$. The decomposition of the vapour is reproducible but complex, both in its kinetics and stoichiometry. It depends on pressure and surface, and can follow either first or second-order kinetics depending on conditions. Products of the decomposition are $\mathrm{N}_{2}, \mathrm{H}_{2}, \mathrm{~N}_{2} \mathrm{H}_{4}$ and probably $\mathrm{NH}_{3}$.

Solid di-imide was found to be very stable, with no appreciable decomposition observed up to the melting point of the solid $\mathrm{NH}_{3}-\mathrm{N}_{2} \mathrm{H}_{2}$ mixture at $-65^{\circ} \mathrm{C}$. Di-imide also appeared to persist for many minutes at least in the liquid mixture with ammonia at temperatures between $-65^{\circ}$ and $-30^{\circ} \mathrm{C}$.

A detailed account of these studies will be published elsewhere.

\section{WILLIS*}

R. A. BACK

Division of Chemistry,

National Research Council of Canada,

100 Sussex Drive, Ottawa

Received October 2, 1972.

*Present address: Chemistry Department, University of the West Indies, Kingston, Jamaica.

${ }^{1}$ Sidgwick, N. V. S., The Chemical Elements and their Compounds, 711 (Oxford University Press, London, 1950).

2 Audrieth, L. F., and Ackerson, B. The Chemistry of Hydrazine, 4 (Chapman and Hall, London, 1951).

${ }^{3}$ Hünig, S., Müller, H. R., and Thier, W., Angew. Chem., 77, 368 (1965).

4 Foner, S., and Hudson, R. L., J. Chem. Phys., 28, 719 (1958).

5 Trombetti, A., Can. J. Phys., 46, 1005 (1968).

6 Mock, W. L., thesis, Harvard University (1964).

\section{BIOLOGICAL SCIENCES}

\section{Ecology of the Ras Muhammad Crack in Sinai}

CRACKS running through raised Pleistocenic coral reefs form a common environment around the tropical Indian and Pacific Oceans. The cracks can be reached only when they have an opening to the surface of the dry raised reef, and therefore the biota found in the open cracks is a mixture of light-avoiding subterranean species and of shadow-loving marine species. Near the southern tip of the Sinai Peninsula, Cape Ras Muhammad (Fig. 1), an open crack of about $40 \mathrm{~m}$ length and $0.20-1.5 \mathrm{~m}$ width and about $150 \mathrm{~m}$ inland, was discovered in October 1971 (Fig. 2). It is possible, with difficulty, to descend into the crack and dive to depths of over $14 \mathrm{~m}$.

Contact with the sea is proved by the fact that the water level in the crack fluctuates with the tides, and the salinity of the water is about equal to that of the open sea: $23.60 \mathrm{~g} \mathrm{l}^{-1}$ against 23.52 in October 1971 , and $22.60 \mathrm{~g} \mathrm{l}^{-1}$ at the surface and $22.80 \mathrm{~g} \mathrm{l}^{-1}$ at $11 \mathrm{~m}$ depth against $23.60 \mathrm{~g} \mathrm{l}^{-1}$ in the neighbouring lagoon.

The steep and shaded walls of the crack are covered with many algae, among them Valonia, Codium, Botryocladia and calcareous red algae, and sponges, monascidians and terebellid and serpulid polychaets. The fauna is dominated by two species of shrimp. According to Holthuis (personal communication), one is a new species of Periclimenes, a transparent pinkish, fairly active species, the other is a new genus of the family 